\title{
Avicularin ameliorates human hepatocellular carcinoma via the regulation of $\mathrm{NF}-\kappa \mathrm{B} / \mathrm{COX}-2 / \mathrm{PPAR}-\boldsymbol{\gamma}$ activities
}

\author{
ZHIMIN WANG ${ }^{1}$, FANG LI ${ }^{1}$, YUAN QUAN ${ }^{2}$ and JUNYE SHEN ${ }^{3}$ \\ ${ }^{1}$ Department of Basic Medicine; ${ }^{2}$ School of Nursing, Qujing Medical College, Qujing, \\ Yunnan 655000; ${ }^{3}$ Department of Traditional Chinese Medicine, Hwa Mei Hospital, University of \\ Chinese Academy of Sciences, Ningbo, Zhejiang 315000, P.R. China
}

Received September 14, 2018; Accepted March 20, 2019

DOI: $10.3892 / \mathrm{mmr} .2019 .10198$

\begin{abstract}
Hepatocellular carcinoma (HCC) has become a global public health problem. Therefore, the development of novel and effective therapeutic agents for the treatment of HCC is considered an emergency. Avicularin, a bio-active flavonoid from plants, has been reported to exhibit diverse pharmacological properties. The aim of the present study was to investigate the role of avicularin in HCC and the underlying mechanism of action. Huh7 cells were treated with avicularin in a concentration-dependent manner, and the cell proliferation was examined using a 3-(4, 5-dimethylthiazol-2-yl)-2, 5-diphenyltetrazolium bromide assay kit. The cell migration and invasion abilities were detected using wounding-healing assays and Transwell assays. Flow cytometric analysis was performed to investigate the cell cycle distribution and cell apoptosis. The activity of nuclear factor (NF)- $\mathrm{kB}$ (p65), cyclooxygenase-2 (COX-2) and peroxisome proliferator-activated receptor $\gamma(\mathrm{PPAR}-\gamma)$ were measured by reverse transcription-quantitative polymerase chain reaction and western blot analyses, respectively. The results indicated that avicularin treatment markedly decreased cell proliferation concentration-dependently in HCC, and inhibited cell migration and invasion in Huh7 cells. It was also found that the treatment of avicularin markedly inhibited the G0/G1-phase cells and decreased the accumulation of S-phase cells in the cell cycle and induced cell apoptosis. In addition, it was confirmed that the anticancer efficacy of avicularin in HCC was dependent on the regulation of NF- $\mathrm{kB}$ (p65), COX-2 and PPAR- $\gamma$ activities. In conclusion, the findings suggested that avicularin serves an antineoplastic role in HCC and may provide a potential therapeutic strategy for the treatment of HCC.
\end{abstract}

Correspondence to: Dr Junye Shen, Department of Traditional Chinese Medicine, Hwa Mei Hospital, University of Chinese Academy of Sciences, 41 Xibei Street, Ningbo, Zhejiang 315000, P.R. China

E-mail: shenjy6611@sina.com

Key words: hepatocellular carcinoma, avicularin, cell proliferation, nuclear factor- $\kappa \mathrm{B}$, cyclooxygenase-2, peroxisome proliferator-activated receptor $\gamma$

\section{Introduction}

Human hepatocellular carcinoma (HCC) is one of the most common types of cancer and the third leading cause of cancer-associated mortality worldwide (1). The incidence of HCC is highest in sub-Saharan Africa and East Asia (2). HCC is a multistep process mainly associated with alcohol, aflatoxin and persistent infection with hepatitis B virus or hepatitis C virus (3). Curative treatments, including locoregional ablation, surgical resection and liver transplantation, are only appropriate for a small number of patients diagnosed at an early stage; the majority of patients are diagnosed with HCC at an advanced disease stage, resulting in a high mortality rate of HCC (4). At present, sorafenib is the unique drug that has been approved by the U.S. Food and Drug Administration (FDA) for patients with advanced HCC (5). However, the majority of patients are unable to afford the high expense of sorafenib, therefore, there is an urgent need for novel therapies.

Several dietary flavonoids, abundant in various fruits and vegetables, are regarded as bioactive components with particular benefit to the health of the body. Accumulating evidence has suggested that flavonoids exert effective biological activity, including anticancer, anti-inflammatory and antiviral effects against infection, in addition to potential protective activity against liver damage (6-8). Avicularin (quercetin-3- $\alpha$-L-arabino furanoside; Fig. 1A), a glycoside of quercetin, is a type of flavonoid which has been reported to inhibit obesity, inflammation and multidrug resistance (9-11). In addition, previous studies have indicated that the quercetin avicularin can induce cytotoxicity in cancer lines and tumor tissues by activating the intrinsic pathway of apoptosis (12). However, the anticancer activity of avicularin itself has been not fully elucidated.

The aim of the present study was to investigate the effects of avicularin on $\mathrm{HCC}$ and its potential mechanism of action in Huh7 cells. It was hypothesized that avicularin has a positive influence on HCC, and that avicularin may be a potential effective and safe therapy for HCC.

\section{Materials and methods}

Cell culture. The Huh7 HCC cells were obtained from the Cell Bank of the Type Culture Collection of the Chinese Academy of Sciences (Shanghai, China). The cells were cultured in 
Dulbecco's Modified Eagle Medium supplemented with $10 \%$ fetal bovine serum (FBS; both Thermo Fisher Scientific, Inc., Waltham, MA, USA), $1 \%$ antibiotics $(100 \mathrm{U} / \mathrm{ml}$ penicillin and $100 \mathrm{mg} / \mathrm{ml}$ streptomycin) and $2 \mathrm{mM}$ glutamine at $37^{\circ} \mathrm{C}$ in a humidified atmosphere of $5 \% \mathrm{CO}_{2}$. The cells were treated with sorafenib ( $5 \mu \mathrm{mol} / 1$; BioVision, Inc.) as the positive control, and treated with different concentrations $(100,50$ and $25 \mu \mathrm{g} / \mathrm{ml})$ of avicularin (Aladdin Biochemical Technology, Co., Ltd., Shanghai, China) as the treatment groups.

Cell viability assay. The cell viability assay was performed using a 3-(4, 5-dimethylthiazol-2-yl)-2, 5-diphenyltetrazolium bromide (MTT; Sigma-Aldrich, Merck KGaA) assay. Briefly, the Huh7 cells were seeded in 96-well plates at a density of $1 \times 10^{4}$ cells/well and incubated overnight at $37^{\circ} \mathrm{C}$. Following incubation, cells were treated with sorafenib/avicularin in $10 \%$ FBS-supplemented medium for 12, 24, 36 and $48 \mathrm{~h}$ at $37^{\circ} \mathrm{C}$, respectively. The medium was replaced with MTT $(0.5 \mathrm{mg} / \mathrm{ml})$ for $4 \mathrm{~h}$ at $37^{\circ} \mathrm{C}$. The resulting formazan crystals were then dissolved in DMSO. The absorbance was determined at $490 \mathrm{~nm}$.

Cell migration assays. The cells were incubated at $5 \times 10^{5}$ per dish with sorafenib or avicularin and grown to confluence for $48 \mathrm{~h}$. Subsequently, a pipette tip was used to generate a wound, vertical to the parallel line (interval of 2-3 mm) marked on the bottom of the dish. After 0 and $48 \mathrm{~h}$, the migration distance was analyzed using Image $\mathbf{J}$ software (version 1.46; National Institutes of Health, Bethesda, MD, USA). The experiments were performed in triplicate.

Transwell invasion assay. The invasion assay of cells was assessed using Transwell cell culture chambers $(8 \mu \mathrm{m}$ pore size; EMD Millipore, Billerica, MA, USA). Briefly, $600 \mu \mathrm{l}$ medium containing $10 \%$ FBS was added to the lower 24-well chamber. The treated cells were resuspended in serum-free medium, and then cultured in the upper chamber coated with $50 \mu \mathrm{l}$ of $1 \mathrm{~g} / \mathrm{l}$ Matrigel (BD Biosciences). After $24 \mathrm{~h}$, the upper side of the membrane was gently wiped with a cotton swab to remove cells whose upper surface did not penetrate, and the membrane was stained with $1 \%$ crystal violet for $20 \mathrm{~min}$ at room temperature, followed by washing with PBS. The invasive cells were counted at $\times 200$ magnification by an Olympus light microscope (BX43; Olympus Corporation, Tokyo, Japan) in five randomly selected fields per well. Each experiment was performed in triplicate.

Reserve transcription-quantitative polymerase chain reaction $(R T-q P C R)$ analysis. Total RNA was isolated with TRIzol (Invitrogen, Thermo Fisher Scientific, Inc.) and complementary DNA was then synthesized with PrimeScript ${ }^{\mathrm{TM}} \mathrm{RT}$ reagent kit (Takara Bio, Inc., Otsu, Japan) using the following conditions: Initial incubation at $37^{\circ} \mathrm{C}$ for $15 \mathrm{~min}$, followed by incubation at $85^{\circ} \mathrm{C}$ for $5 \mathrm{sec}$. Subsequently, qPCR was performed by FastStart Universal SYBR-Green Master (Roche Diagnostics, Mannheim, Germany) according to the manufacturer's protocols. The qPCR thermocycling conditions were as follows: Initial denaturation at $95^{\circ} \mathrm{C}$ for $10 \mathrm{~min}$, followed by 40 cycles of $95^{\circ} \mathrm{C}$ for $10 \mathrm{sec}$ and $60^{\circ} \mathrm{C}$ for $60 \mathrm{sec}$. The relative mRNA expression was calculated using the $2^{-\Delta \Delta \mathrm{Cq}}$ method (13), and normalized using GAPDH as the reference gene. The following primers were used for the experiment: Nuclear factor (NF)- $\mathrm{kB}$ (p65) forward, 5'-ACGATCTGTTTCCCCTCATCT-3' and reverse, 5'-TGCTTCTCTCCCCAGGAATA-3'; peroxisome proliferator-activated receptor $\gamma($ PPAR- $\gamma)$ forward, 5'-AAC TGCAGGGTGAA AC TCTGGGAGATTCTCC-3' and reverse, 5'-GGATTCAGCAACCATTGGGTCAGCTCT-3'; cyclooxygenase-2 (COX-2), forward, 5'-CTGAGGGGTTAC CATTCCA-3' and reverse, 5'-TGAGCAAGTCCGTGTTC AAG-3'; GAPDH forward, 5'-GTGAGGAGGGGAGATT CAG-3' and reverse, 5'-GCATCCTGGGCTACACTG-3'.

Western blot analysis. The cells were lysed with RIPA buffer $(50 \mathrm{mM}$ Tris-HCl, pH 7.4; $0.15 \mathrm{M} \mathrm{NaCl} ; 1 \%$ Nonidet $\mathrm{P}-40,0.1 \%$ sodium dodecyl sulfate and $0.5 \%$ sodium deoxycholate) containing protease and phosphatase inhibitors (Sigma-Aldrich, Merck KGaA), and the protein concentration was measured using a BCA protein assay kit (Pierce, Thermo Fisher Scientific, Inc.). The same amount $(20 \mu \mathrm{g})$ of proteins were separated on $10 \%$ SDS-PAGE gels and transferred onto Immobilon polyvinylidene difluoride membranes (EMD Millipore), and then blocked in 5\% skim milk in TBST for $1 \mathrm{~h}$ at room temperature. The primary antibodies against $\mathrm{COX}-2$ (1:500; cat. no. ab23672), PPAR- $\gamma$ (1:500; cat. no. ab45036), NF-кB (p65) (1:2,000; cat. no. ab86299) and GAPDH (1:2,500; cat. no. ab9485; Abcam, Cambridge, UK) were added for overnight incubation at $4^{\circ} \mathrm{C}$. Following washing three times with 1 X TBST buffer, a secondary antibody coupled to horseradish peroxidase (1:2,000; cat. no. sc-2030) from Santa Cruz Biotechnology, Inc. was incubated with the membranes for $1.5 \mathrm{~h}$ at room temperature, and immunoactivity was detected using an ECL-Plus kit (GE Healthcare Life Sciences, Pollards Wood, UK). Band intensity on scanned films was quantified using ImageJ software (version 1.46; National Institutes of Health, Bethesda, MD, USA) and expressed as relative intensity compared with control. The intensity of the protein bands was normalized to GAPDH and the relative intensity was calculated.

Flow cytometric analysis. Following treatment for $48 \mathrm{~h}$, the cells were harvested and washed in cold PBS. For cell cycle analysis, the cells were fixed in $70 \%$ ethanol at $-20^{\circ} \mathrm{C}$ overnight. Following washing and centrifugation at $1,000 \mathrm{x}$ g for $5 \mathrm{~min}$ at $4^{\circ} \mathrm{C}$, the cells were treated with RNase $A$ and stained with propidium iodide (PI) working solution for $30 \mathrm{~min}$ in the dark. Analysis was determined using a FACS Caliber flow cytometer and CellQuest software (version 5.1; BD Biosciences). For the analysis of cell apoptosis, the Annexin-V-FITC Apoptosis Detection kit I (BD Pharmingen) was used, according to the manufacturer's protocol. Briefly, the cells were resuspended with $1 \mathrm{X}$ binding buffer, following which the cells were stained with $5 \mu \mathrm{l}$ Annexin-V-FITC and $5 \mu \mathrm{l} \mathrm{PI}$, and then incubated in the dark for $15 \mathrm{~min}$. Subsequently, the appropriate $1 \mathrm{X}$ binding buffer was added and apoptosis was analyzed by the FACSCalibur flow cytometer.

Statistical analysis. Statistical analysis was performed using GraphPad Prism 6.0 (GraphPad Software, Inc., La Jolla, CA, USA). The results are expressed as the mean \pm standard deviation from at least three independent experiments. Statistical 
A<smiles>O=c1c(O)c(-c2ccc(O)c(O)c2)oc2cc(O)cc(O)c12</smiles>

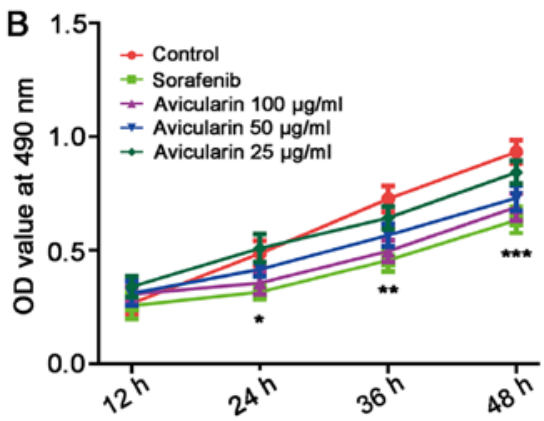

Figure 1. Avicularin inhibits Huh7 cell proliferation in hepatocellular carcinoma. (A) Chemical structure of avicularin. (B) Proliferation of Huh7 cells was determined using a 3-(4, 5-dimethylthiazol-2-yl)-2, 5-diphenyltetrazolium bromide assay. OD values at $490 \mathrm{~nm}$ were observed at $12,24,36$ and $48 \mathrm{~h}$, respectively. Data are presented as the mean \pm standard deviation of three experiments. ${ }^{*} \mathrm{P}<0.05,{ }^{* *} \mathrm{P}<0.01$ and ${ }^{* * *} \mathrm{P}<0.001$, vs. control. OD, optical density.

A
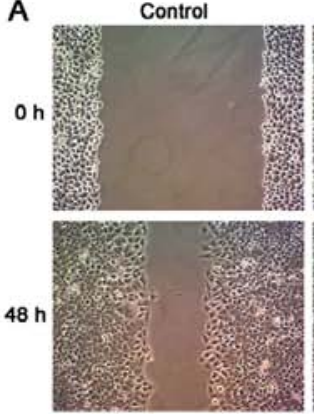

B

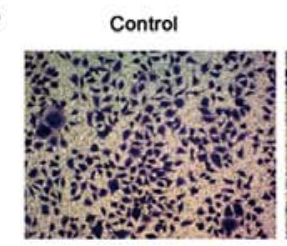

Sorafenib

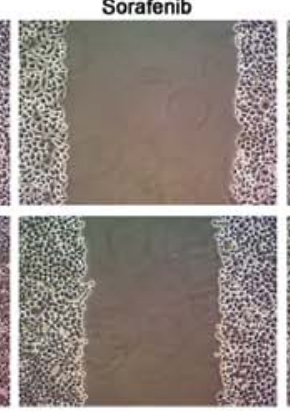

Sorafenib

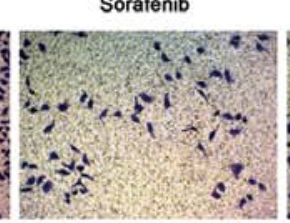

Avicularin $100 \mu \mathrm{g} / \mathrm{ml}$

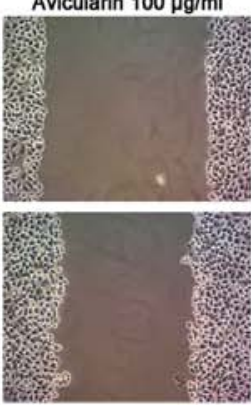

Avicularin $100 \mu \mathrm{g} / \mathrm{ml}$

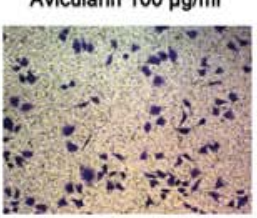

Avicularin $50 \mu \mathrm{g} / \mathrm{ml}$

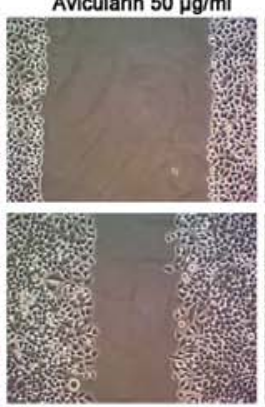

Avicularin $50 \mu \mathrm{g} / \mathrm{ml}$

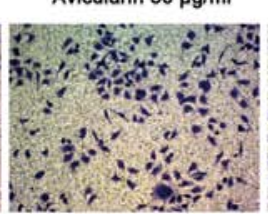

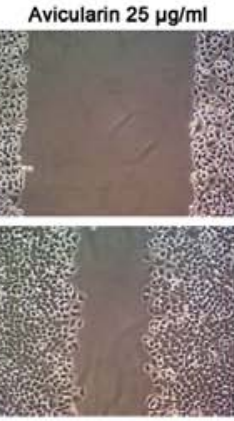
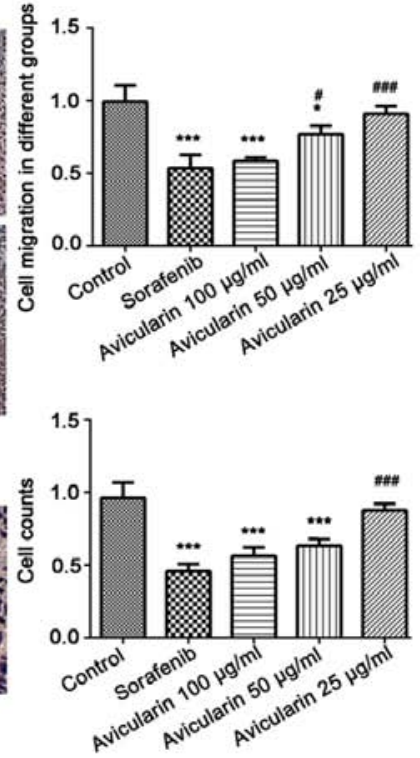

Figure 2. Avicularin repress the migration and invasion of Huh7 cells. (A) Wounding-healing assays and (B) Transwell assays were used to investigate the changes in the migratory and invasive abilities of Huh7 cells following treatment with sorafenib and avicularin. All results were quantified. Magnification, $\mathrm{x} 200$. Data are presented as the mean \pm standard deviation of three experiments. ${ }^{*} \mathrm{P}<0.05$ and ${ }^{* * * *} \mathrm{P}<0.001$, vs. control; ${ }^{\#} \mathrm{P}<0.05$ and ${ }^{\# \# \#} \mathrm{P}<0.001$, vs. sorafenib.

significance was analyzed using a two-tailed Student's t-test. $\mathrm{P}<0.05$ was considered to indicate a statistically significant difference.

\section{Results}

Avicularin inhibits the proliferation of Huh7 cells. The physiological effect of avicularin on HCC was investigated by observing the proliferation of Huh7 cells treated with avicularin. As shown in Fig. 1B, sorafenib, an oral multikinase inhibitor approved for advanced HCC (5), resulted in marked inhibition of cell proliferation. Avicularin significantly inhibited cell proliferation in a concentration-dependent manner. With the growth of Huh7 cells cultured with avicularin, the suppressing effect of avicularin on cell proliferation was more marked.

Avicularin repress the migration and invasion of $\mathrm{Huh} 7 \mathrm{cells.} \mathrm{To}$ confirm that avicularin functions as tumor suppressor in $\mathrm{HCC}$, the present study investigated the influence of avicularin on the migration and invasion of Huh cells. The results suggested that the wounding healing of Huh7 cells was markedly retarded in the presence of sorafenib and avicularin (Fig. 2A). Therefore avicularin suppressed cell migration following treatment at concentrations of 100 and $50 \mu \mathrm{g} / \mathrm{ml}$, and was concentration-dependent. Additionally, the invasive ability of Huh7 cells cultured under sorafenib/avicularin was observed through a Transwell assay. As shown in Fig. 2B, compared with the control cells, the cell counts were markedly decreased following sorafenib and avicularin treatment. Avicularin resulted in a marked inhibition of cell invasion at the concentrations of 100 and $50 \mu \mathrm{g} / \mathrm{ml}$. As a result, avicularin effectively suppressed the migration and invasion of Huh7 cells in HCC.

Avicularin promotes cell apoptosis and regulates cell cycle progression. To determine the effects of avicularin on cell cycle, the cells were treated with different concentrations $(25,50$ and $100 \mu \mathrm{g} / \mathrm{ml})$ of avicularin for $48 \mathrm{~h}$, and the percentage of cells in different cell cycle phases were analyzed. As shown in Fig. 3A and B, compared with the control cells, sorafenib and avicularin induced notable G0/G1 arrest in the Huh7 cells. Additionally, there was a marked decrease in the accumulation of S-phase cells in the avicularin-treated group, similar 

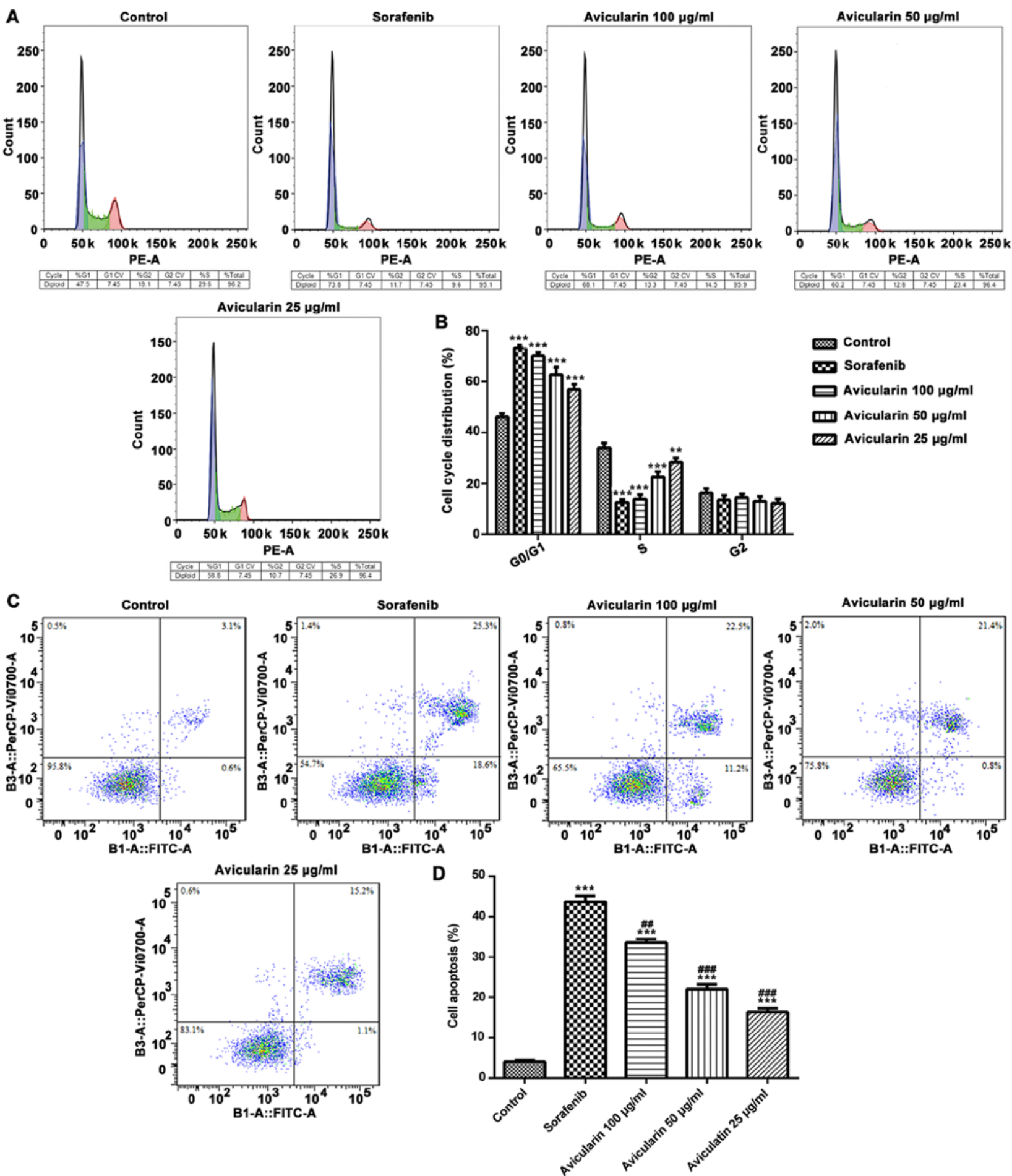

Figure 3. Cell were stained with propidium iodide and the cell cycle distributions and cell apoptosis were measured by flow cytometry. (A) Effects of avicularin on the cycle distribution of Huh7 cells. (B) Quantification of cells in each phase of the cell cycle. (C) Cell apoptosis was analyzed and (D) quantified. Data are presented as the mean \pm standard deviation of three experiments. ${ }^{* *} \mathrm{P}<0.01$ and ${ }^{* * *} \mathrm{P}<0.001$, vs. control; ${ }^{\# \#} \mathrm{P}<0.01$ and ${ }^{\# \# \#} \mathrm{P}<0.001$, vs. sorafenib.

to sorafenib, particularly at the concentration of $100 \mu \mathrm{g} / \mathrm{ml}$. These data suggested that the inhibition of cell proliferation by avicularin was connected with an increase in the G0/G1 phase and a decrease in the $\mathrm{S}$ phase of the cell cycle.

In order to assess whether avicularin inhibited cell proliferation through an apoptotic mechanism in $\mathrm{HCC}$, flow cytometric analysis was performed in Huh7 cells. As shown in Fig. 3C and D, the percentage of cell apoptosis was increased in the sorafenib-treated cells. It was confirmed that avicularin enhanced cell apoptosis, which occurred in a concentration-dependent manner. The above results demonstrated that avicularin regulates cell cycle progression and promotes cell apoptosis, which may lead to the inhibition of cell proliferation in HCC.

Avicularin serves an antineoplastic role through the regulation of $N F-\kappa B$ (p65), $C O X-2$ and $P P A R-\gamma$. Subsequently, to gain further insight into the mechanism underlying the 

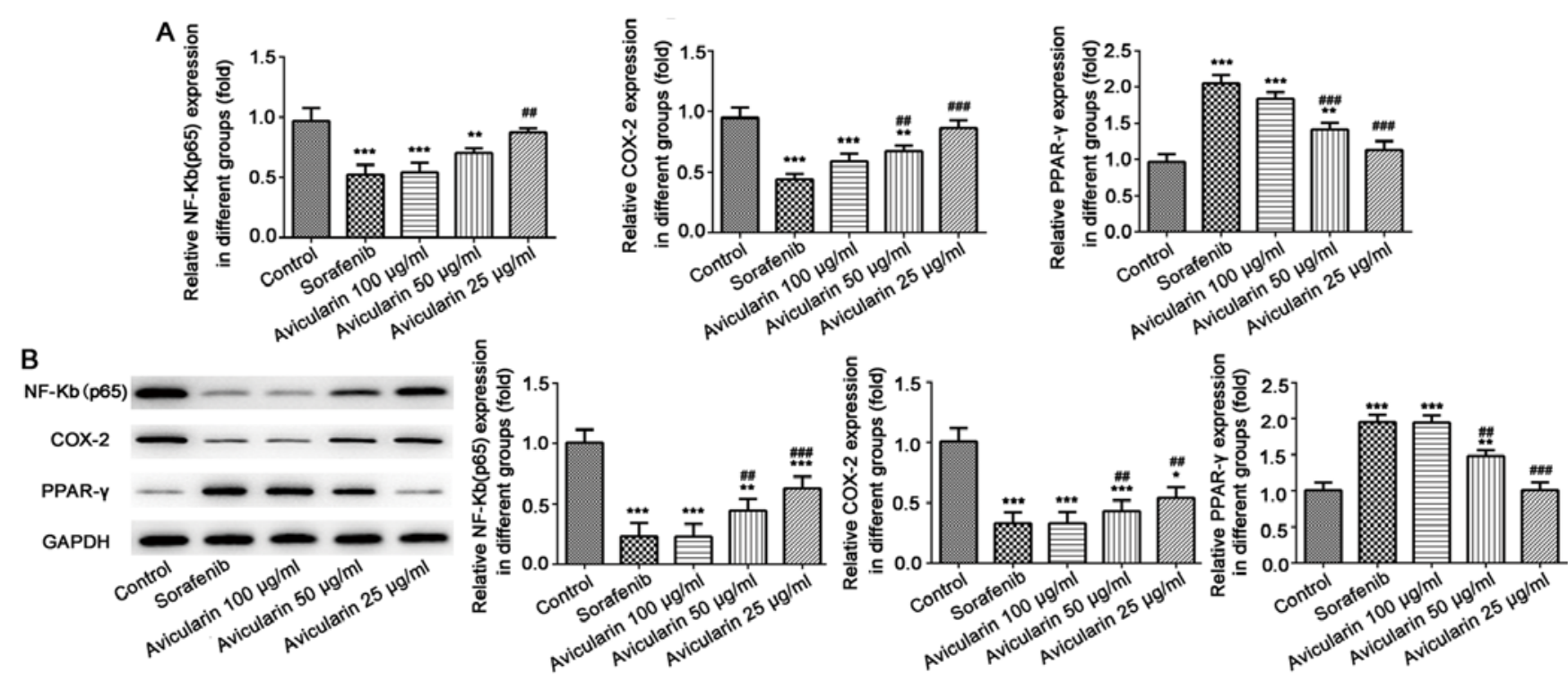

Figure 4. Expression of NF-kB (p65), COX-2 and PPAR- $\gamma$. (A) Following treatment with sorafenib and avicularin, the mRNA levels of NF- $\mathrm{kB}$ (p65), COX-2 and PPAR- $\gamma$ was measured by reverse transcription-quantitative polymerase chain reaction analysis. (B) Protein expression of NF- $\mathrm{kB}$ (p65), COX-2 and PPAR- $\gamma$ was measured by western blot analysis and quantified. Data is presented as the mean \pm standard deviation of three experiments. ${ }^{*} \mathrm{P}<0.05,{ }^{* *} \mathrm{P}<0.01$ and ${ }^{* * * *} \mathrm{P}<0.001, \mathrm{vs} . \operatorname{control}$; ${ }^{\# \#} \mathrm{P}<0.01$ and ${ }^{\# \#} \mathrm{P}<0.001$, vs. sorafenib. NF- $\mathrm{kB}$, nuclear factor- $\mathrm{kB}$; COX-2, cyclooxygenase-2; PPAR $\gamma$, peroxisome proliferator-activated receptor $\gamma$.

antiproliferative activity of avicularin in HCC, the present study aimed to determine whether avicularin-induced

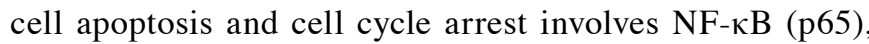
COX-2 and PPAR- $\gamma$, which have been known to be involved in cell cycle progression and proliferation. As shown in Fig. 4A and B, sorafenib resulted in significant inhibition of NF- $\mathrm{BB}$ (p65) and COX-2, not only at the mRNA level, but also at the protein level. The mRNA level and protein expression levels of PPAR- $\gamma$ were increased. Similarly, avicularin resulted in the same effects on NF- $\kappa \mathrm{B}$ (p65), COX-2 and PPAR- $\gamma$ in a concentration-dependent manner. Taken together, these results suggest that avicularin regulates cell apoptosis and cell cycle via the downregulation of NF- $\mathrm{KB}$ (p65) and COX-2 and the upregulation of PPAR- $\gamma$.

\section{Discussion}

HCC is a global public health problem that accounts for a high rate of morality. Currently, liver resection, liver transplantation and ablation remain the mainstream treatment, which are only appropriate for those patients at an early stage and can easily result in adverse effects. Therefore, to overcome these deficiencies, sorafenib, approved by the FDA, has been shown to be effective against several solid tumors and is a standard treatment for HCC (14). Previous studies have reported that sorafenib exerts its antitumor activities by triggering cell apoptosis and inhibiting tumor angiogenesis through the Raf, c-kit, vascular endothelial growth factor, platelet-derived growth factor, fms-like tyrosine kinase 3 and mitogen-activated protein kinase pathways $(5,15)$. In addition, it is reported that sorafenib can reduce Alzheimer's disease pathology by reducing neuroinflammation through inhibition of the expression of NF- $\kappa \mathrm{B}$ and COX-2 (16). In the present study, it was found that sorafenib also targets NF- $\mathrm{KB}$ and COX-2 to exert its antineoplastic role. However, as the high cost of sorafenib makes is difficult to afford, it remains essential to develop more effective, safe and appropriate methods for the treatment of HCC. In the present study, a novel therapy against $\mathrm{HCC}$ was investigated and its mechanism of anticancer activity was examined. It was found that avicularin inhibited the proliferation, migration and invasion of Huh7 cells in HCC through influencing cell apoptosis and cycle distribution on the regulation of NF- $\mathrm{kB}(\mathrm{p} 65), \mathrm{COX}-2$ and PPAR- $\gamma$.

In oriental culture, numerous plants have been used in folk medicine for thousands of years. Among abundant plants, the flavonoid family, as a group of plant secondary metabolites with multiple phenolic structures, is of particular interest and is usually found in vegetables and fruits (17). It has been reported that numerous flavonoids can enhance the efficacy and alleviate the adverse effects of tumor therapies. Baicalein and silymarin, extracts of Scutellaria baicalensis, have been shown to exert a suppressive effect on tumors. The combination of baicalein and silymarin can suppress HepG2 cell proliferation by increasing the percentages of cells in the $\mathrm{G} 0 / \mathrm{G} 1$ phase and decreasing those in the $\mathrm{S}$ phase (18). Amentoflavone, a flavonoid compound extracted from Selaginella tamariscina Spring, reportedly exerts antineoplastic activity via the induction of cell apoptosis and inhibition of glycolysis in HCC (19). Additionally, baicalein (20), tectorigenin (21) and other flavonoids have been shown to protect cells against cancer progression though the activation of proapoptotic and antiproliferative pathways or other pathways (22). Avicularin (quercetin-3- $\alpha$-L-arabinofuran oside) belongs to a group of flavonoid glycosides. It has been reported that avicularin has a protective effect against human gastric cancer through inducing apoptosis dependent on Bax and BCL-2-related ovarian killer (11). The present study focused on the efficacy of avicularin on HCC. The data showed that avicularin exerted marked anticancer activity in Huh7 cells in a concentration-dependent manner. Avicularin at $100 \mu \mathrm{g} / \mathrm{ml}$ had a marked suppressive effect on cell proliferation, migration and invasion, similar to sorafenib. However, at a concentration at $25 \mu \mathrm{g} / \mathrm{ml}$, avicularin had no effect on HCC. 
$\mathrm{NF}-\kappa \mathrm{B}$ is a protein complex that controls the transcription of DNA (23). It is a key transcription factor that is closely associated with the proliferation and apoptosis of cancer, and it also serves an important role in the cell cycle, which is vital in determining the degree of cellular proliferation and apoptosis. In the present study, the cell population was increased in the G0/G1 phase but decreased in the $S$ phase. Cell apoptosis was improved following treatment with avicularin. The mRNA level and protein expression levels of p65 (a subunit of NF- $\mathrm{NB}$ ) were significantly inhibited by avicularin, which indicates that avicularin suppressed cell cycle progression and promoted cell apoptosis via the inhibition of $\mathrm{NF}-\kappa \mathrm{B}$ activity. The involvement of COX-2 in tumorigenesis in $\mathrm{HCC}$ has been widely reported in several studies, and is also closely linked with $\mathrm{NF}-\kappa \mathrm{B}$. The promoter regions of the COX-2 gene in human and mice harbor binding sites for $\mathrm{NF}-\kappa \mathrm{B}$. Therefore the expression of COX-2 can be mediated via NF- $\kappa \mathrm{B}$ (24). Accordingly, the results of the present study showed that avicularin markedly downregulated the mRNA and protein expression levels of COX-2 in Huh7 cells. Therefore, it is possible that avicularin exerts its anticancer activity on the inhibition of COX-2 through NF- $\kappa$ B.

PPAR $-\gamma$ is a member of the nuclear hormone receptor superfamily. It is involved in the control of biological processes associated with differentiation, growth, apoptosis and cell cycle (25). The activity of PPAR- $\gamma$ has been shown to be inhibited in HCC (26). The overexpression of PPAR- $\gamma$ can inhibit cell proliferation in HCC, and the downregulation of PPAR- $\gamma$ has been associated with differentiation and poor prognosis in patients in HCC (27). PPAR- $\gamma$ is also reported to be correlated with cell cycle arrest through p53 and p21 (28). Additionally, PPAR- $\gamma$ promotes cell apoptosis, which resulted in the inhibition of cancer (29). Based on these results, the present data showed that the expression of PPAR- $\gamma$ was significantly increased when the cells were treated with sorafenib and avicularin. The anticancer activity of avicularin involved in the inhibition of cell proliferation, migration and invasion, and changes in cell apoptosis and cell cycle may partly depend on the upregulation of PPAR- $\gamma$.

In conclusion, the results demonstrate an antineoplastic role of avicularin of HCC in vitro. It was clearly demonstrated that avicularin can inhibit cell proliferation, migration and invasion in HCC through inducing apoptosis and suppressing cell cycle progression. Additionally, the decreased activity of $\mathrm{NF}-\kappa \mathrm{B}$ and COX-2 and increased activity of PPAR $-\gamma$ suggest that avicularin has an antineoplastic effect through the regulation of these, and that NF- $\kappa \mathrm{B}, \mathrm{COX}-2$ and PPAR- $\gamma$ are vital factors predicting the anticancer effect in HCC. Overall, the results of the present study suggests that avicularin may be a valuable therapeutic agent in the treatment of HCC.

\section{Acknowledgements}

Not applicable.

\section{Funding}

The present study was supported by the Health and Family Planning Commission of Zhejiang Province (grant no. GZS2012031)

\section{Availability of data and materials}

The datasets used and/or analyzed during the present study are available from the corresponding author on reasonable request.

\section{Authors' contributions}

JS was involved in the design of the experiment. ZM, FL and YQ performed the experiments and analyzed the data. ZM and YQ wrote the manuscript. JS reviewed and edited the manuscript. All authors read and approved the manuscript.

\section{Ethics approval and consent to participate}

Not applicable.

\section{Patient consent for publication}

Not applicable.

\section{Competing interests}

The authors declare that they have no competing interests.

\section{References}

1. Lu T, Seto WK, Zhu RX, Lai CL and Yuen MF: Prevention of hepatocellular carcinoma in chronic viral hepatitis B and $\mathrm{C}$ infection. World J Gastroenterol 19: 8887-8894, 2003.

2. Torre LA, Bray F, Siegel RL, Ferlay J, Lortet-Tieulent J and Jemal A: Global cancer statistics, 2012. CA Cancer J Clin 65: 87-108, 2015.

3. El-Serag HB and Rudolph KL: Hepatocellular carcinoma: Epidemiology and molecular carcinogenesis. Gastroenterology 132: 2557-2576, 2007.

4. Yang JD and Roberts LR: Hepatocellular carcinoma: A global view. Nat Rev Gastroenterol Hepatol 7: 448-458, 2010.

5. Jiang X, Feng K, Zhang Y, Li Z, Zhou F, Dou H and Wang T: Sorafenib and DE605, a novel c-Met inhibitor, synergistically suppress hepatocellular carcinoma. Oncotarget 6: 12340-12356, 2015.

6. Cui X, Wang Y, Kokudo N, Fang D and Tang W: Traditional Chinese medicine and related active compounds against hepatitis B virus infection. Biosci Trends 4: 39-47, 2010.

7. Williams RJ, Spencer JP and Rice-Evans C: Flavonoids: Antioxidants or signalling molecules? Free Radic Biol Med 36: 838-849, 2004.

8. Handoussa H, Osmanova N, Ayoub N and Mahran L: Spicatic acid: A 4-carboxygentisic acid from Gentiana spicata extract with potential hepatoprotective activity. Drug Discov Ther 3: 278-286, 2009.

9. Fujimori K and Shibano M: Avicularin, a plant flavonoid, suppresses lipid accumulation through repression of $\mathrm{C} / \mathrm{EBP} \alpha$-activated GLUT4-mediated glucose uptake in 3T3-L1 cells. J Agric Food Chem 61: 5139-5147, 2013.

10. Vo VA, Lee JW, Chang JE, Kim JY, Kim NH, Lee HJ, Kim SS, Chun W and Kwon YS: Avicularin inhibits lipopolysaccharide-induced inflammatory response by suppressing ERK phosphorylation in RAW 264.7 macrophages. Biomol Ther (Seoul) 20: 532-537, 2012.

11. Guo XF, Liu JP, Ma SQ, Zhang P and Sun WD: Avicularin reversed multidrug-resistance in human gastric cancer through enhancing Bax and BOK expressions. Biomed Pharmacother 103: 67-74, 2018.

12. Srivastava S, Somasagara RR, Hegde M, Nishana M, Tadi SK, Srivastava M, Choudhary B and Raghavan SC: Quercetin, a natural flavonoid interacts with DNA, Arrests cell cycle and causes tumor regression by activating mitochondrial pathway of apoptosis. Sci Rep 6: 24049, 2016. 
13. Livak KJ and Schmittgen TD: Analysis of relative gene expression data using real-time quantitative PCR and the 2(-Delta Delta C(T)) method. Methods 25: 402-408, 2001.

14. Lang L: FDA approves sorafenib for patients with inoperable liver cancer. Gastroenterology 134: 379, 2008.

15. Hahn O and Stadler W: Sorafenib. Curr Opin Oncol 18: 615-621, 2006.

16. Echeverria V, Burgess S, Gamble-George J, Zeitlin R, Lin X, Cao C and Arendash GW: Sorafenib inhibits nuclear factor kappa B, decreases inducible nitric oxide synthase and cyclooxygenase- 2 expression, and restores working memory in APPswe mice. Neuroscience 162: 1220-1231, 2009.

17. Nijveldt RJ, van Nood E, van Hoorn DE, Boelens PG, van Norren $K$ and van Leeuwen PA: Flavonoids: A review of probable mechanisms of action and potential applications. Am J Clin Nutr 74: 418-425, 2001.

18. Chen $\mathrm{CH}$, Huang TS, Wong $\mathrm{CH}$, Hong CL, Tsai YH, Liang CC, Lu FJ and Chang WH: Synergistic anti-cancer effect of baicalein and silymarin on human hepatoma HepG2 cells. Food Chem Toxicol 47: 638-644, 2009.

19. Liu B and Yu S: Amentoflavone suppresses hepatocellular carcinoma by repressing hexokinase 2 expression through inhibiting JAK2/STAT3 signaling. Biomed Pharmacother 107: 243-253, 2018.

20. Liang RR, Zhang S, Qi JA, Wang ZD, Li J, Liu PJ, Huang C, Le XF, Yang J and Li ZF: Preferential inhibition of hepatocellular carcinoma by the flavonoid Baicalein through blocking MEK-ERK signaling. Int J Oncol 41: 969-978, 2012.

21. Jiang CP, Ding H, Shi DH, Wang YR, Li EG and Wu JH: Pro-apoptotic effects of tectorigenin on human hepatocellular carcinoma HepG2 cells. World J Gastroenterol 18: 1753-1764, 2012.

22. Garcia ER, Gutierrez EA, de Melo FCSA, Novaes RD and Goncalves RV: Flavonoids effects on hepatocellular carcinoma in murine models: A systematic review. Evid Based Complement Alternat Med 2018: 6328970, 2018.
23. Gilmore TD: Introduction to NF-kappaB: Players, pathways, perspectives. Oncogene 25: 6680-6684, 2006.

24. Kim JH, Na HK, Pak YK, Lee YS, Lee SJ, Moon A and Surh YJ: Roles of ERK and p38 mitogen-activated protein kinases in phorbol ester-induced NF-kappaB activation and COX-2 expression in human breast epithelial cells. Chem Biol Interact 171: 133-141, 2008.

25. Koeffler HP: Peroxisome proliferator-activated receptor gamma and cancers. Clin Cancer Res 9: 1-9, 2003.

26. Vara D, Morell C, Rodriguez-Henche N and Diaz-Laviada I: Involvement of PPARgamma in the antitumoral action of cannabinoids on hepatocellular carcinoma. Cell Death Dis 4: e618, 2013.

27. Li S, Li J, Fei BY, Shao D, Pan Y, Mo ZH, Sun BZ, Zhang D, Zheng X, Zhang M, et al: MiR-27a promotes hepatocellular carcinoma cell proliferation through suppression of its target gene peroxisome proliferator-activated receptor $\gamma$. Chin Med J (Engl) 128: 941-947, 2015

28. Galli A, Ceni E, Mello T, Polvani S, Tarocchi M, Buccoliero F, Lisi F, Cioni L, Ottanelli B, Foresta V, et al: Thiazolidinediones inhibit hepatocarcinogenesis in hepatitis B virus-transgenic mice by peroxisome proliferator-activated receptor gamma-independent regulation of nucleophosmin. Hepatology 52: 493-505, 2010

29. Yu J, Shen B, Chu ES, Teoh N, Cheung KF, Wu CW, Wang S, Lam CN, Feng H, Zhao J, et al: Inhibitory role of peroxisome proliferator-activated receptor gamma in hepatocarcinogenesis in mice and in vitro. Hepatology 51: 2008-2019, 2010.

This work is licensed under a Creative Commons Attribution-NonCommercial-NoDerivatives 4.0 International (CC BY-NC-ND 4.0) License. 